\author{
FIDEL RODRÍGUEZ LEGENDRE, GEMMA RUIZ VARELA \\ Francisco de Vitoria University, Madrid, Spain \\ ORCID: 0000-0002-8329-3712,f.rodriguez.prof@ufv.es \\ ORCID: 0000-0002-9957-8050,g.ruiz@ufv.es
}

\title{
Music and Creativity as Educational Strategies for Sociability. Group Dynamics with Students Pursuing Educational Degrees from the Francisco de Vitoria University in Madrid
}

This research work deals with making use of resources related to musical instruction in order to generate strategies for achieving the following objectives: 1) establishing group interaction where cooperative relationships are defined and the roles and forms of leadership are distributed under the logic of group dynamics; 2) stimulating creativity related to musical improvisation based on producing simple sound and rhythmic structures; 3) achieving a state when students are capable of acquiring a musical experience, regardless of whether they have any academic training in conservatories or music schools. In order to achieve these objectives, we have applied such musical resources as percussion instruments (triangles, metallophones, tambourines, Chinese boxes, tom-toms...), proposed unconventional forms of musical notation and resorted to the use of percussion instruments from the Afro-Caribbean region (bongos, congas and timbales) as means for improvisation. In the latter instance, the aim is to generate group dynamics by use of resources linked to the art of sound. Stemming from a group vision of university education, the experience of a methodology centred on music is proposed as a means of provoking and arousing the dynamics of sociability, which is necessary for achieving integral formation for students.

Keywords: innovation; dialogical practices; methodology of teaching.

For citation / Для ияитирования: Ruiz Varela G., Rodríguez Legendre F. Music and Creativity as Educational Strategies for Sociability. Group Dynamics with Students Pursuing Educational Degrees from the Francisco de Vitoria University in Madrid // Проблемы музыкальной науки. 2020. № 1. C. 110-121. DOI: 10.33779/2587-6341.2020.1.110-121.

\section{ФИДЕЛЬ РОДРИГЕС ЛЕГЕНДРЕ ГЕММА РУИС ВАРЕЛА}

Университет Франсиско де Витория, г. Мадрид, Испания ORCID: 0000-0002-8329-3712,f.rodriguez.prof@ufv.es

ORCID: 0000-0002-9957-8050,g.ruiz@ufv.es

\section{Музыка и творчество как образовательные стратегии развития коммуникабельности. Активные групповые занятия со студентами педагогической специализации Университета Франсиско де Витория, Мадрид}

В данной публикации показано использование ресурсов, связанных с обучением музыке, для выработки стратегий, направленных на достижение следующих целей: 1) установить 
взаимодействие в группе, определяя отношения сотрудничества, распределение ролей и форм лидерства в соответствии с логикой динамики группы; 2) стимулировать творчество или музыкальную импровизацию, основанную на работе с простыми ладовыми и ритмическими структурами; 3) добиться, чтобы студенты могли приблизиться к музыкальному опыту, независимо от того, имеют ли они какое-либо академическое образование в консерваториях или музыкальных школах. Для достижения этих целей использованы музыкальные ресурсы в виде ударных инструментов (треугольники, металлофоны, бубны, китайские шкатулки, барабаны...), предлагаются формы нотной записи (нетрадиционные), подключаются афрокарибские ударные инструменты (бонги, конги и тимбалес) для импровизации. В последнем случае задача состоит в том, чтобы создать активную группу, опираясь на ресурсы, имеющиеся в искусстве звуков. На групповых занятиях в университете опыт методики музыкальной педагогики видится как способ усиления динамики коммуникаций, необходимой для достижения целостного образования студентов.

Ключевые слова: инновации, практика диалога, методика обучения.

\section{INTRODUCTION}

In recent years there has been a significant advancement in musical education, due, among other factors, to contributions from other spheres of knowledge which surpass musical pedagogy. At the same time, music has also been used as a resource for establishing certain strategies linked to social psychology, microsociology and group dynamics, taking the analysis of social interactions as a basis for work. In this sense, it is important to point out that the various musical ensembles engaged in musical performance are, in reality, microgroups composed of performers: vocalists and instrumentalists who are required to carry out coordinated forms of social interaction while interpreting music.

Infact, instrumental performancerequires from the musicians the implementation of a form of communication which, despite its non-verbal nature, is necessarily required to incorporate agreements, dialogues, and forms of coordination in order to guarantee an effective configuration of musical structure and a continuous flow of elements of sound, which must be deciphered both by members of the group itself and by recipients of the musical experience in their various modalities and means of dissemination.

Taking the previous elements as a basis, it is important to clarify that interpretation of music, understood by us as a form of social interaction, operates both for the field of academic music, as for popular music. In the first case, we refer to the instrumentalist who achieves his training in conservatories and music schools, bearing in mind the acquisition of a technical level for performance on his instrument and the ability to read the conventional forms of notation, where his interpretation is based on the use of the pentagram, in addition to possible additional coaching, in some cases, of a choral or orchestral director. In the case of popular music, we speak of a non-regulated formation of a musician, achieved in a self-taught way, with the inherent ability to integrate with other musicians, which, on many occasions, incorporates the practice of improvisation.

In this sense, based on the aforementioned considerations, we have within the groups where musical coordination operates a microcosm of social interaction in which musicians operate as processing units within the framework of a system in motion, whose purpose is to direct the communication of 
musical information of aesthetic, sensory and emotional varieties, one which must be decoded by the public. And it is from this conception of musical micro-groups that we propose the possibility of generating strategies of sociability, the latter being understood as one of the basic types of social interaction.

\section{MUSICAL PRACTICE AS A FORM OF SOCIAL INTERACTION. REVIEW OF STUDIES}

The theoretical basis of the present approach is based on the latest research in the field of cognitive neuroscience, whose objective has been focused on the study of cognition processes for brain organization. At this point it is important to point out that studies of neuro-cerebral functioning have been carried out with individual people in an isolated manner, without taking into account any of their possible interactions with other subjects. However, beginning from the experimental rigor, studies have been carried out as a point of departure from the neuro-cerebral functioning of an individual taking into account his social interactions with other individuals: in other words, it begins from the experiences associated with social interactions for the study of the neuro-cerebral processes of man.

One of the most effective proposals for the study of neuro-cognitive processes based on social interactions has been the one proposed by the researcher D'Ausilio, who has raised the possibility of carrying out ecological tests of cognition and brain functions using musical groups playing instruments in real time as study samples, at the same time as significant measurements are being made. The fundamental principle here is that different forms of musical interaction in which music is a participant are characterized by non-verbal forms of communication, which allow the establishment of specific parameter measurements [2, pp. 111-112].

Based on the above assessments, we understand that musical groups can be comprehended as social interaction groups in which individuals are defined as integrated processing units within the social-musical group (a complex system) performing joint actions with common objectives on emotional, creative, aesthetic and technical levels. But the substantive point is that there is an exchange of information taking place which may operate at a sensory level with non-verbal forms of expression; These nonverbal forms of expression are associated with body motions and facial gestures: head motions, body motion, body expressivity, etc. $[10$, p. 1]. For the aforementioned reasons, the study of social interactions through social-musical groups has begun to take priority over the study of sensory and motor communication. This circumstance has led to the elaboration of a taxonomy of socio-musical interactions on a group level.

For this present research, we shall apply the taxonomic approach of interactions elaborated by D'Ausilio, Novembre, Fadiga and Keller [2] in which experimental designs are established for the study of musical interactions, which are measured in two dimensions: experimental control and ecological interaction. The level of experimental control is associated with the use of technological devices which can record the sounds created by the musician and which can generate a virtual musical accompaniment through the use of in-form programs. The level of ecological interaction is associated with the influence of other musicians able to establish social-musical groups, of which there must be no less than two in number. Starting from these two axes of organization, D'Ausilio establishes 5 levels: (A) labelled as the "recording," where the individual interacts with a computer 
program recording the created sounds; (B) labelled as the "virtual companion," consisting particularly of "a virtual partner" controlled by a computer and to which the individual responds and follows musically; (C) labelled as the "duo," consisting of interaction between two individuals; (D) labelled as the "mixed group," consisting of more than two individuals who can participate in mixed ensembles, including the format of the orchestra; (E) labelled as "live music," where the group also interacts with the listeners who comprise the live audience.

These different taxonomic levels make it possible for different quantities of response to be obtained in the processes of social interaction, a circumstance which will depend, in the first place, on the levels of manipulation of the forms of ecological interaction and experimental control. On this aspect, D'Ausilio explains the different levels of control between both levels in the following terms:

"This continuum allows hypotheses to be tested through systematic manipulations of musical interaction that are parametrically graded in terms of the degree of ecological naturalness and experimental control. As ecological validity increases, the directionality of the interaction becomes more complex: from unidirectional, to bidirectional or multidirectional, involving a computer, other musicians, and also an audience. Increasing ecological validity offers the possibility to explore natural and unconstrained interaction, but it is also associated with higher uncertainty concerning the actions of others, which implies decreasing experimental control (Box 1). The taxonomy we propose may be used to guide the process of testing whether findings from tightly controlled contexts generalize to progressively richer ecological settings" [2, p. 113].

It is important to point out that there have been precedents regarding studies of collective musical practices under theoretical conceptions linked to the sociology of music and psychology. One of the most important antecedents may be found in the approaches of the German sociologist Alphons Silbermann, who was possibly one of the first social scientists to propose the category of social-musical groups for the study of music departing from group sociology, and to understand music as a social fact, since it generates sociability. In his approach he spoke of social-musical groups of producers (musicians, performers, composers, etc.) and social-musical groups of consumers. However, his proposal did not elaborate categories or concepts which made it possible to analyse social interactions in musical practice [9].

For purposes of the present research, we shall take the conceptualization and the taxonomy on the social group proposed by D'Ausilio [2], starting from the category labelled as "mixed group" (group D), which as we have indicated, consists of more than two individuals who can participate in mixed sets. This type of group (D) shall be our reference for the proposal of socialeducational dynamics which make it possible, on the one hand, to generate sociability and, on the other hand, to stimulate practices associated with creativity, or what is also called "creative intelligence," according to the approach of Robert Sternberg [7, pp. 63-81]. For this purpose, we shall adopt the format of group dynamics using music, its language and resources as a cohesion practice. In this sense, the group is conceived as a space for social interaction which can apply, for certain purposes, structures of nonverbal language (music), where the forms of interaction shall be mediated by forms of playful association.

\section{METHODOLOGY}

1. Explanation shall be given of the strategies carried out with the aim of 
generating processes of social interaction between groups of students, in order to achieve the following goals.

2. We shall motivate processes allowing the student to gain access to the aesthetic experience, understood as a way which allows the individual and the group to create meaning through the use of nonverbal language forms associated with the organization of sounds, timbres and structuring of instrumental assemblies.

3. We shall help the student, or groups of students to achieve forms of self-perception and self-construction which would make it possible for them to recognize themselves as creators of modes of expression and symbolic manifestations.

4. Experiences related to emotional education in the area of music of the Degree in Early Childhood Education shall be addressed.

5. Artistic creativity (creative intelligence) and musical improvisation shall be stimulated.

\section{Description of the activity by phases}

1. In the first part of the dynamics, the instructor must create the environment of preparation and contact with the parameters of music. For this purpose, use has been made of Dalcroze's proposal [1, pp. 27-33; 4, pp. 141-167], where it is pointed out that study of music is achieved through bodily motion based on imitation of musical parameters, such as sound, height, rhythm, etc. through one's own body. From this idea, the first dynamics is established with the use of sounds of a theremin ${ }^{1}$, which must be imitated with motion of hands by the student group. At this point it is important to note that each student is required to cover his or her face with a mask which prevents any kind of visibility, focusing his or her attention on the use of the auditory sense, and to move his or her hands in correspondence with the variation of the sounds from rough to sharp recording. Then the musical score is demonstrated to the students showing the approximate sounds used for the session (Figure 1).

Figure 1: Theremin Score

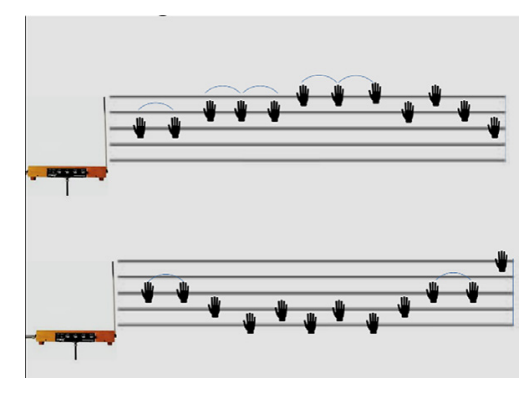

Source: Original

2. As part of the second action, the students are organized in groups of 6 people, and particular resources are given to them; the first group is assigned to play pitched percussion instruments with keyboards (the xylophone, campanelli, metallophone and marimba); the second group is assigned accessory percussion instruments (the triangle, cymbals, cowbell, castanets, wood blocks and tambourine); the third group is given drumsticks to play redo-blades; The fourth group is assigned membranophones (the snare drum, tenor drum, drums and timbales) and finally, the fifth group is assigned to play Afro-Latin percussion instruments (bongos, congas and timbales).

\footnotetext{
${ }^{1}$ The theremin (théremin or théreminvox), called the etherophon in its primitive version, is one of the first electronic musical instruments. Invented in 1919 by the Russian physicist and musician Lev Sergeevich Termen (who then altered his name in the French manner to Leon Théremin).
} 
3. The following instructions are offered:

3.1. Organization of groups;

3.2. Choice of a group leader who coordinates the activity. This action will allow the assignment of roles to achieve a more effective degree of social interaction and guarantee the experience of sociability;

3.3. Directed assignment of instruments by the instructor;

3.4. Explanation of the rules of creative activity, by the instructor;

3.3. Distribution of the workspace in a multipurpose room, or any other suitable spatial distribution of the workspace in a multipurpose room;

3.4. The time for group work shall amount precisely to 30 minutes;

3.5. Interpretation of the composition;

3.6. An alternate form of annotation shall be provided which does not necessarily require the use of note and staff figures.

4. As we have stated before, the instructor shall provide musical scores with different rhythmic-melodic cells suitable for each ensemble, and the students, in addition to performing them verbatim, shall be required to depart from them in the direction of improvising or engaging themselves in the processes of composing original music. Each group shall be assigned the following instructions in order to recreate certain rhythmic and melodic structures:

a) The students playing the keyboard instruments must use a pair of drumsticks for each instrument, the rhythms and durations must be based on the use of round, white and black indications of durations, and for each instrument a maximum of four different notes shall be used. From the third measure, the students playing the glockenspiel, the xylophone and the vibraphone must improvise a diverse rhythms and pitches, while the two marimbas maintain the same rhythmic and melodic patterns. The tempo must be Moderato (Figure 2).
Figure 2: Rhythmic Patterns in the Muscal Score

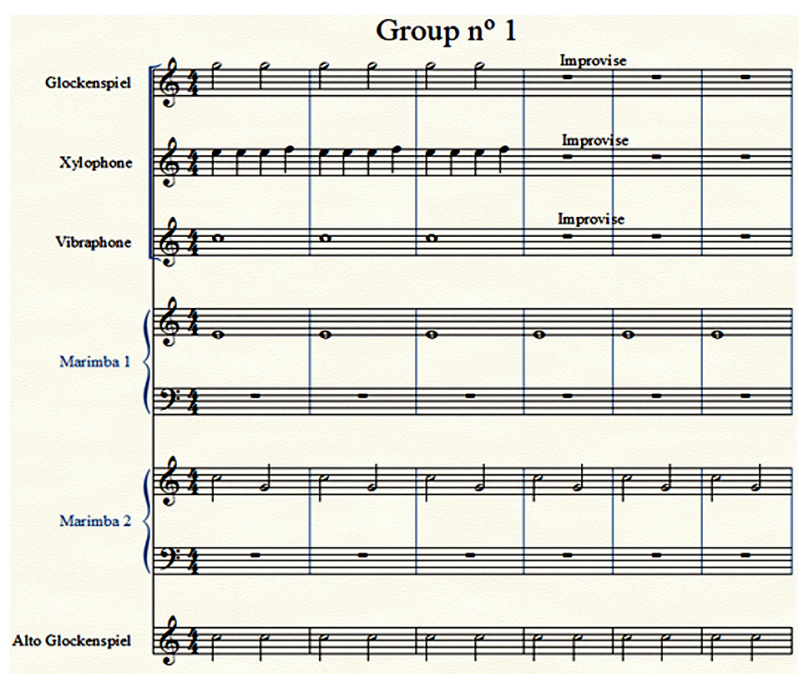

Source: Original

b) Percussion accessory instruments: students must play in the basic rhythms provided by the teacher. These rhythms must be structured with the use of eighth and sixteenth notes. From the third measure, half of the members of the group, most notably, those playing the triangle, the finger cymbals and the cow-bell must improvise different rhythms based on the use of eighth-note and quarter-note durations (Figure 3).

Figure 3: Musical Score with Rhythmic Patterns in the Percussion Instruments

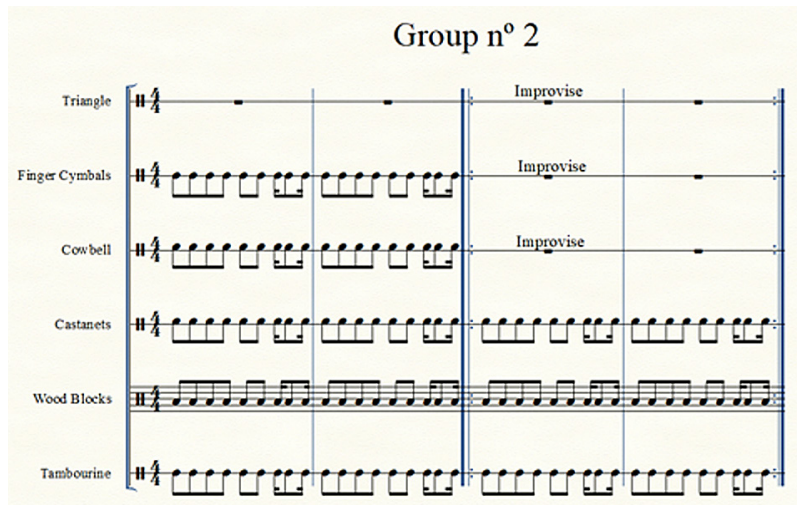

Source: Original

c) Drumsticks: The basic rhythm proposed shall be composed of eighth and sixteenth notes. In such cases, the students must only use sticks which can be applied 
to create percussive effects on the floor, on the wall, or against each other. They may also combine their playing with percussive sounds produced with their feet. From m. 6, half of the group must improvise rhythmic structures combining eighth-note durations and rests (Figure 4).

Figure 4: Score with Rhythmic Patterns for Drumsticks Group $\mathrm{N}^{\circ} 3$

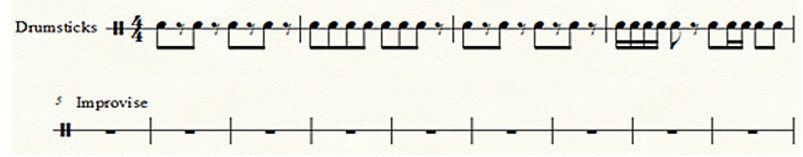

Source: Original

d) Membranophones: The timpani and bass drum must produce the basic rhythm sounds, while the snare drums (2 units) and tenor drums (2 units) must improvise rhythms using quarter-note durations (Figure 5).

Figure 5: Score Drumsticks

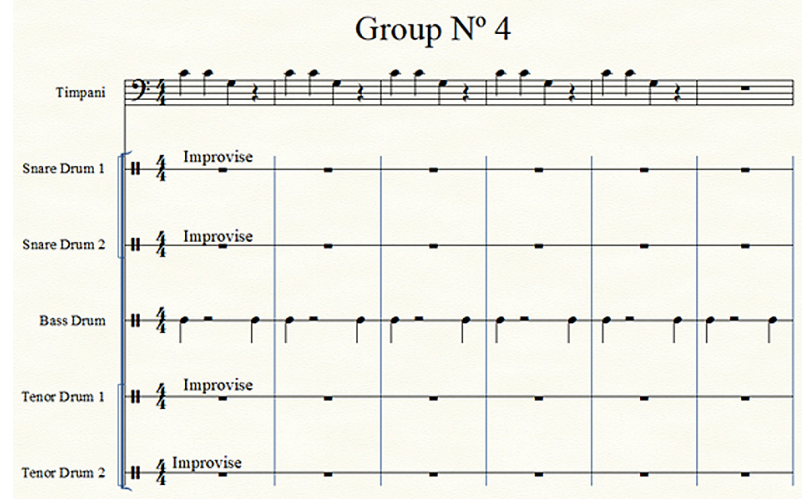

Source: Original

e) Afro-Latin percussion instruments: for this last modality, the cymbals (2 units) must execute the indicated rhythm of a syncopated character, while the bongos and congas ( 2 units) must perform improvised rhythms which include the use of double patterns with figures of sixteenth-note, eighth-note and triplet durations, starting from m. 3 (Figure 6).
Figure 6: Score with Rhythmic Patterns for Drumsticks

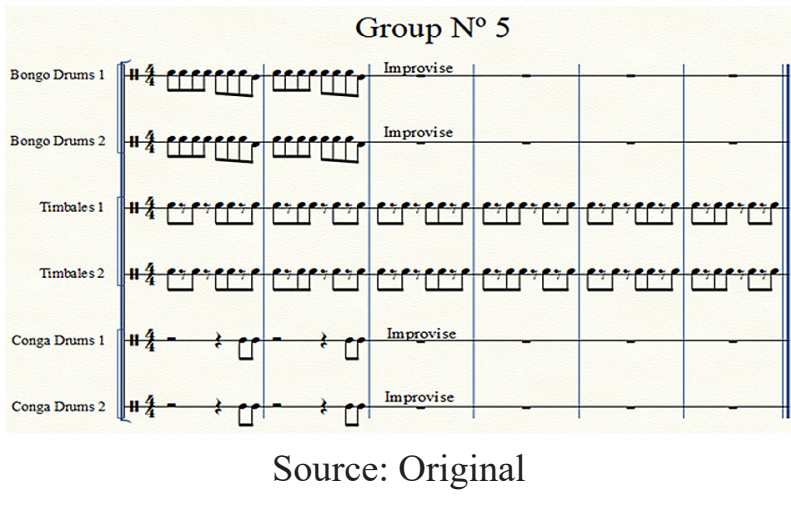

5. After completion of the musical activity, the students must be given questionnaires to evaluate the effectiveness of the instructive process.

\section{DATA ANALYSIS: EVALUATION OF THE ACTIVITY}

Following these activities, an account shall be given of the aspects related to the processed example and data, obtained when the activity was explained in the previous section, by means of questionnaires.

\section{Methodology}

For the present research, a quantitative type of methodology and a nonexperimental design have been used. The form of a "survey" has been applied as a method of collecting information from our example, consistent with the students who participated in the activity. This survey is given in the form of a "questionnaire" to ascertain the participants' level of satisfaction with the activities and their perception of the stimulation of artistic creativity, most notably, in the form of musical improvisation, through ten multiple choice questions, with a habitual format in this type of investigations [5]. The study variables are, respectively, that of "musical creativity" and "sociability." Up to the present time, we have not discovered any validation study in the 
context of Spanish musicology of any scale which measures these two variables quantitatively, so we shall proceed to fulfilling the task of validating the scale, the descriptive study and the correlational analysis of the aforementioned, to assess the possible relationships between the two study variables: "musical creativity" and "sociability."

\section{Statistics and Samples}

The statistics of our results have been defined by all the students of the Degree in Early Childhood Education of the Francisco de Vitoria University during the 2018-2019 academic year. We use an accidental nonprobabilistic sampling technique. The process consisted in informing about the activity all students enrolled in the field of studies labelled as Development of Artistic Expression who are eligible to participate voluntarily in it, which took place on April 30, 2019. In this symposium 30 students aged between 18 and 22 attended the group dynamics which were taught that day, of which 100\% were women and students of the Department of Early Childhood Education at the University of Francisco de Vitoria

\section{Treatment of the data}

According to the SPSS Statistics, 22 programs has been used for data analysis. The developed analyses are articulated in two types: descriptive analysis and correlational analysis. Basic descriptive analyses are carried out (absolute frequencies, percentages and measures of central tendency and dispersion for the variables contemplated in the study). Regarding correlational analysis, the Pearson correlation coefficient has been applied to assess whether there are relationships between the variables studied, especially to comprehend the possible relationships between the two study variables, "musical creativity" and "sociability." Once these considerations are established, we turn to expose the results obtained in the investigation.

\section{Instrument}

The questionnaire designed for this activity, establishes a scale of 10 items comprised of two dimensions and a higher factor called "music-sociability." Up to the present day, this scale has not been applied before, hence, there is no validation study in the context of Spanish scholarship. A validation of the scale is carried out.

\section{Results of the evaluation of the main variables}

When performing the analysis of the answers by items, we can emphasize that the total number of the students considers that the objectives proposed in the activity regarding the variable of "sociability" have been met. If we analyse the average scores by each item (Table 1), it is necessary for us to point out that all the nuclei have obtained an average of scores higher than 4.87 out of 6 , with a minimum average score of 4.87 and a maximum score of $5,4,5$. In order to check the homogeneity of the valuations of each item, we have calculated the Pearson Variation Coefficient, whose main function is to facilitate the comparison of the dispersion of two data series. In our study, it takes values between 0.14 for the item "cooperative work" and 0.21 for the item "shared responsibility," The values taken by this coefficient, since they are close to zero, indicate that there is little variability between the data, they are not dispersed with respect to the average, which presents us with a high amount of homogeneity in the evaluations. 
Table 1. Measures of the Central Tendency and Dispersion - Sociability

\begin{tabular}{|l|c|c|c|c|c|}
\hline \multicolumn{1}{|c|}{ Statisticians } & $\begin{array}{c}\text { Team } \\
\text { interdependence }\end{array}$ & $\begin{array}{c}\text { Shared } \\
\text { responsibility }\end{array}$ & Foster consensus & $\begin{array}{c}\text { Cooperative } \\
\text { work }\end{array}$ & $\begin{array}{c}\text { Dialogue } \\
\text { decision making }\end{array}$ \\
\hline Average & 4,87 & 4,94 & 5,19 & 5,45 & 5,10 \\
\hline Median & 5,00 & 5,00 & 5,00 & 6,00 & 5,00 \\
\hline Moda & 5,00 & 6,00 & 6,00 & 6,00 & 6,00 \\
\hline Variance & 0,72 & 1,13 & 0,96 & 0,66 & 0,76 \\
\hline S.D. & 0,85 & 1,06 & 0,98 & 0,81 & 0,87 \\
\hline Variation C. & $17,37 \%$ & $21,53 \%$ & $18,88 \%$ & $14,86 \%$ & $17,07 \%$ \\
\hline
\end{tabular}

Source: SPSS

To examine the internal consistency of the valuations, the Alpha Coefficient of Cronbach has been calculated, which obtains the value of 0.84 (Table 2). According to the recommendations collected by George and Mallery [3, p. 231] in order to assess this coefficient, we can state that it is close to being an excellent coefficient.

Table 2. Cronbach's Alpha

\begin{tabular}{|c|c|}
\hline Cronbach's Alpha & $\begin{array}{c}\text { Cronbach's Alpha } \\
\text { with typified elements }\end{array}$ \\
\hline, 84 &, 85 \\
\hline
\end{tabular}

Source: SPSS

Next, we present a third table which evaluates the students about the variable of "musical creativity." If we analyse the average of the scores by each item (Table 3), we must point out that all of the items have obtained an average of scores higher than
4.6 out of 6 , with the minimum average score being 4.5 and the maximum score being 5.47. To test the homogeneity of the valuations of each item, we have calculated the Pearson Variation Coefficient, whose main function is to facilitate the comparison of the dispersion of two data series. In our study, it takes values between 0.15 for the item "collective creativity" and 0.27 for the item "musical dexterity." The values taken by this coefficient, because they are close to zero, express that there is little variability between the data, they are not dispersed with respect to the average, which presents us with a high homogeneity in the valuations.

To examine the internal consistency of the evaluations, the Cronbach Alpha Coefficient has been calculated, which obtains a value of 0.84 (Table 4 ). We can state that it is close to being an excellent coefficient.

Table 3. Measures of central tendency and dispersion - Creativity

\begin{tabular}{|l|c|c|c|c|c|}
\hline \multicolumn{1}{|c|}{ Statisticians } & CREATIVITY & $\begin{array}{c}\text { MUSICAL } \\
\text { MOTIVATION }\end{array}$ & $\begin{array}{c}\text { MUSICAL } \\
\text { DEXTERITY }\end{array}$ & $\begin{array}{c}\text { DISCOVERING } \\
\text { NEW } \\
\text { INSTRUMENTS }\end{array}$ & $\begin{array}{c}\text { COLLECTIVE } \\
\text { CREATIVITY }\end{array}$ \\
\hline Average & 5,20 & 5,14 & 4,50 & 4,67 & 5,47 \\
\hline Median & 5,50 & 5,00 & 4,50 & 5,00 & 6,00 \\
\hline Moda & 6,00 & 6,00 & 4,00 & 5,00 & 6,00 \\
\hline Variance & 0,99 & 1,05 & 1,50 & 1,68 & 0,74 \\
\hline S.D. & 1,00 & 1,03 & 1,22 & 1,30 & 0,86 \\
\hline Variation C. & 19,16 & 19,96 & 27,22 & 27,76 & 15,74 \\
\hline
\end{tabular}

Source: SPSS 
Table 4. Cronbach's Alpha

\begin{tabular}{|l|l|}
\hline Cronbach's Alpha & $\begin{array}{l}\text { Cronbach's Alpha with } \\
\text { typified elements }\end{array}$ \\
\hline, 84 &, 85 \\
\hline
\end{tabular}

Source: SPSS

The correlations between nuclei are almost all positive, all being very high and significant in their level. The highest correlations are between the "interdependence of the team" and the rest of the items, and between "music motivation" and the rest of the study items (Table 5).

\section{CONCLUSION}

The first observation of importance is associated with the effectiveness of the group dynamics that has been used, based on the introduction of musical resources. This first conclusion is based on the data obtained in relation to the items which allow measuring the variable linked to sociability. It was divided into 5 sub-dimensions: team interdependence, shared responsibility, consensus building, cooperative work and dialogue in decision-making.

From the statistical results, we observe that on a Likert scale of $0-6$, the data oscillate between 4.87 and 5.45 (out of 6), with a low variability of the same. Although all sub-dimensions show a satisfactory result, a brief comment can be made regarding the sub-dimension "Interdependence of the team," with the lowest result of the five (4.87). This circumstance can most likely be explained by the differences in the musical formation of the different students of the course; consequently, for future analyses and studies, the influence of the variable musical formation must be controlled statistically. On the other hand, the subdivision "Cooperative work" (5.45) demonstrates a very effective result, which can be explained by the incidence of methodologies associated with this type of work taught in the Department of Early Childhood Education: Sociology of

Table 5. Correlation

\begin{tabular}{|c|c|c|c|c|c|c|c|c|c|c|}
\hline ITEMS & $\begin{array}{c}\text { Team } \\
\text { interdependence }\end{array}$ & $\begin{array}{c}\text { Shared } \\
\text { responibility }\end{array}$ & $\begin{array}{l}\text { Promote } \\
\text { consensus }\end{array}$ & $\begin{array}{l}\text { Team } \\
\text { work }\end{array}$ & $\begin{array}{l}\text { Dialogue } \\
\text { decisión } \\
\text { making }\end{array}$ & Creativity & $\begin{array}{c}\text { Music } \\
\text { motivation }\end{array}$ & $\begin{array}{l}\text { Musical } \\
\text { dexterity }\end{array}$ & $\begin{array}{c}\text { Discovering } \\
\text { new } \\
\text { instruments }\end{array}$ & $\begin{array}{l}\text { Collective } \\
\text { creativity }\end{array}$ \\
\hline $\begin{array}{c}\text { Team } \\
\text { interdependence }\end{array}$ & 1 &, $944 * *$ &, $933 * *$ &, $924 * *$ &, $931^{* *}$ & ,960** &, $962 * *$ &, $914 * *$ &, $905 * *$ &, $924 * *$ \\
\hline $\begin{array}{c}\text { Shared } \\
\text { responibility }\end{array}$ & & 1 &, $955^{* *}$ & ,909** & ,946** & , $957 * *$ &, $943 * *$ &, $934 * *$ &, $920 * *$ &, $913 * *$ \\
\hline $\begin{array}{l}\text { Promote } \\
\text { consensus }\end{array}$ & & & 1 & , $947 * *$ &, $949 * *$ & , $942 * *$ &, $943 * *$ &, $913 * *$ &, $917 * *$ &, $932 * *$ \\
\hline Team work & & & & 1 &, $935 * *$ &, $928 * *$ &, $903 * *$ &, $849 * *$ &, $847 * *$ & ,956** \\
\hline $\begin{array}{c}\text { Dialogue } \\
\text { decisión making }\end{array}$ & & & & & 1 &, $938 * *$ &, $915^{* *}$ &, $910 * *$ &, $889 * *$ &, $928 * *$ \\
\hline Creativity & & & & & & 1 &, $974 * *$ &, $926 * *$ &, $907 * *$ &, $956^{* *}$ \\
\hline $\begin{array}{c}\text { Music } \\
\text { motivation }\end{array}$ & & & & & & & 1 &, $940 * *$ &, $922 * *$ &, $933 * *$ \\
\hline $\begin{array}{l}\text { Musical } \\
\text { dexterity }\end{array}$ & & & & & & & & 1 &, $956^{* *}$ &, $880 * *$ \\
\hline $\begin{array}{c}\text { Discovering } \\
\text { new instruments }\end{array}$ & & & & & & & & & 1 &, $859 * *$ \\
\hline $\begin{array}{l}\text { Collective } \\
\text { creativity }\end{array}$ & & & & & & & & & & 1 \\
\hline
\end{tabular}

Source: SPSS ** The correlation is significant at the 0.01 level (bilateral) 
Education, Psychology of Education, Social Responsibility, etc. [6, pp. 145-154].

The second conclusion is linked to the data obtained in relation to the items which allow measuring the variable "Creativity." This has been divided into $5 \mathrm{sub}$ dimensions: creativity, motivation for music, musical dexterity, discovery of new instruments and collective creation. With regard to this dimension, positive results have also been observed, which range in scores from 4.50 to 5.47 on the Likert scale of $0-6$. In this sense, the dynamics of the proposed group generate competences linked to collective action, in order to have access to what we could call "aesthetic experience," even surpassing the sub-dimension associated with creativity. On the other hand, the subdimension "musical skill" obtained the lowest score (4.50), a circumstance which can be explained possibly by the difference in terms of musical training levels, where there are even students present who lack any training, or who have received only the basic school-level musical education.

Finally, the correlations between the nuclei are all positive, very high and significant, being able to register the interdependence of the equipment and the musical motivation as the sub dimensions with the highest level of correlation. This statistical result apparently gives validity credits to musical practice as a social phenomenon which can generate sociability, as the musical sociologist Silberman expresses it. In this sense, music is presented as an effective tool for teaching "social and civic," as well as "cultural and artistic" competences.

\section{DIDACTIC IMPLICATIONS}

The first important didactic implication is that music as a social practice becomes an importantcomponentbothfor the educational process and for practices linked to creativity and the acquisition of social competences. In addition, it allows the design of diverse group dynamics which can be based on the feasibility of aesthetic experiences aimed at developing a positive self-perception in a student. This point is fundamental, since a positive self-perception on the part of the student presents the possibility for the creation of signification, whether individual or collective.

The second implication, as we have pointed out in our previous research, is that the direct use of musical instruments generates in the student motivational behaviour which encourages him to participate actively in the arising dynamics [8, p. 53]. In this sense it is important to emphasize that, regardless of the skills that the student handles to play instruments, various forms of participation are always produced.

Finally, the results of this and previous studies encourage us to improve the design of our questionnaires, introducing control variables which show information about the musical knowledge of our students, the type of musical training they have received (whether official or unofficial), the types of known instruments and their previous artistic experience.

\section{Or REFERENCES $\sqrt{O}$}

1. Anderson W.T. The DalcrozeApproach to Music Education: Theory and Applications. National Association for Music Education. New York, 2014, pp. 27-33.

2. D'Ausilio A, Novembre G, Fadiga L, Keller P. E. What Can Music Tell us About Social Interaction? Trends of Cognitive Science USA, 2015, pp. 111-114. 
3. George D., and Mallery P. SPSS for Windows Step by Step: A Simple Guide and Reference. Boston: Update, Allyn \& Bacon, 2003. 400 p.

4. Juntunen M. L. The Dalcroze Approach. Experiencing and Knowing Music Through Embodied Exploration. Approaches to Teaching General Music: Methods, Issues and Viewpoints. C. R. Abril \& B. Gault (Eds.). Oxford University Press, pp. 141-167.

5. Martín Arribas M. C. Desing and validation os questionnaires. Midwives Profession. Madrid. 2004, pp. 23-29.

6. Martín L., Ros I., and Ruiz G. Emotional education in a film workshop: interdisciplinary proposal and cooperative learning in the school. Emotional Education: Reflexions and areas of application. Madrid: Francisco de Vitoria University, 2014, pp. 127-154.

7. Rodríguez Legendre F. Música y Inteligencia Emocional. Emotional Education: Reflexions and areas of application. Madrid: Francisco de Vitoria University, 2014, pp. 63-81.

8. Ruiz Gemma V., Rodríguez Fidel L. Music as a Tool for Integral Formation in the University. A Proposal of Education in the Meeting. Problemy muzykal'noj nauki / Music Scholarship. 2018. No. 4, pp. 45-54. DOI: 10.17674/1997-0854.2018.4.045-054.

9. Silberman A. The social structure of music. Madrid: Taurus, 1961. $306 \mathrm{p}$.

10. Volpe G. et al. 2016 Measuring social interaction in music ensembles Phil. Trans. R. Soc. B. England: 2016, pp. 1-8.

About the authors:

Fidel Rodríguez Legendre, Ph.D. (Communication Sciences and Sociology, Universidad Complutense de Madrid), Ph.D. (History, Central University of Venezuela), Professor, Vice Dean of Academic and Quality Management, Department of Education and Humanities, Francisco de Vitoria University (28223, Madrid, Spain), ORCID: 0000-0002-8329-3712, f.rodriguez.prof@ufv.es

Gemma Ruiz Varela, Ph.D. (Education and Humanities, Francisco de Vitoria University), Vice Dean of Academic and Quality Management, Faculty of Education and Humanities, Faculty Member of the Department of Humanities, Francisco de Vitoria University (28223, Madrid, Spain), ORCID: 0000-0002-9957-8050,g.ruiz@ufv.es

\section{Об авторах:}

Родригес Легендре Фидель, Ph.D. (Коммуникации и социология, Мадридский университет Комплутенсе), Ph.D. (История, Центральный университет Венесуэлы), профессор, заместитель декана по учебной работе и управлению качеством образования Факультета образования и гуманитарных наук, Университет Франсиско де Витория (28223, г. Мадрид, Испания), ORCID: 0000-0002-8329-3712, f.rodriguez.prof@ufv.es

Руис Варела Гемма, Ph.D. (Образование и гуманитарные науки, Университет Франсиско де Витория), заместитель декана по учебной работе и управлению качеством образования Факультета образования и гуманитарных наук, преподаватель кафедры гуманитарных наук, Университет Франсиско де Витория (28223, г. Мадрид, Испания), ORCID: 0000-0002-9957-8050,g.ruiz@ufv.es 